\title{
STUDENTS' INCONSISTENCY PROBLEMS IN PRONOUNCING DIPHTHONG SOUNDS IN READING ALOUD ACTIVITY AT ENGLISH DEPARTMENT OF STKIP PGRI SUMATERA BARAT
}

\author{
Irvan Haiko Rasaki ${ }^{1)}$, M. Khairi Ikhsan ${ }^{2)}$, Astuti Pratiwi ${ }^{3)}$ \\ STKIP PGRI Sumatera Barat, Indonesia \\ E-mail: ${ }^{1}$ irvanhairaski@gmail.com, ${ }^{2}$ khairi84ikhsan@gmail.com, \\ 3astutipratiwi09@gmail.com \\ Submitted:13-08-2018 Reviewed:12-09-2018 Accepted:25-09-2018 \\ DOI: https://doi.org/10.22202/tus.2018.v4i2.2800
}

\begin{abstract}
Abstrak
Ketidakkonsistenan dalam melafalkan bunyi rangkap vokal adalah suatu permasalahan yang sering kali ditemukan pada pelajar dalam melafalkan suatu bunyi huruf. Penelitian ini bertujuan untuk mendeskripsikan tentang ketidakkonsistenan bunyi rangkap vokal yang dilafalkan oleh mahasiswa dalam aktifitas membaca dengan suara lantang. Penelitian ini merupakan penelitian deskriptif. Sampel pada penelitian ini adalah mahasiswa tahun kedua program studi Pendidikan Bahasa Inggris STKIP PGRI Sumatera Barat yang berjumlah 9 mahasiswa yang mendapatkan nilai standar hingga minimum dalam mata kuliah pronunciation dari sesi yang berbeda berdasarkan kebutuhan penelitian yang memiliki masalah dalam pelafalan bunyi pada aktifitas membaca dengan lantang yang dilihat pada ketidakkonsistenan melafalkan rangkap vokal. Data dikumpulkan dengan melakukan pengamatan melalui instrumen pendukung penelitian yaitu tes dan rekaman video. Test adalah instrumen yang diberikan kepada sampel dengan bentuk teks untuk dibaca dengan suara lantang yang mengandung bunyi vokal rangkap dalam pengamatan pronunciation, serta rekaman video sebagai instrumen perekam yang bertujuan untuk menganalisa bunyi rangkap vokal yang tidakkonsisten yang dilafalkan mahasiswa dalam aktifitas membaca dengan suara lantang. Hasil dari analisa penelitian ini, terdapat 5 buah bunyi yang tidak konsisten dalam pelafalannya, yaitu bunyi. [əə], [er], [ar], dan [əひ].
\end{abstract}

\section{Kata kunci : Diftong, Ketidakkonsistenan, Membaca}

\section{INTRODUCTION}

Pronunciation is a learning of the way how to produce words by using arbitrary system and a graphic representation of the way a word spoken, using phonetic symbols. According to Harmer (2007:281), "pronunciation is the way we make sounds of the language how and where we place the stress, and how we use 
pitch and intonation to show how we are feeling and what we mean". In pronunciation, especially in producing the sounds it would be seen from the way of sounds produce, producing sounds of pronunciation needs practice to build the feeling of means. Understandable pronunciation is one of the basic requirements of learners' competence and it is also one of the most important features of language instruction. It also be explained by Gilakjani (2012:96) defined that pronunciation is a set habits of producing sounds. The habit of producing a sound is acquired by repeating it over and over again by being corrected when it is pronounced wrongly.

In English, there are divided 45 phonemes which are consisted by; 24 consonants, 12 vowels, and 9 diphthongs in segmental features (phonemes), which have variant sound for each sound symbol. For this study, it is specified to focus to the diphthong sound, and it also describes vowel sounds as the description where the diphthong sounds be descended. Diphthongs are a combination of single vowels in the same time to be sounded. Ladefoged (2005:29) stated a diphthong is a sound whose vowel quality changes within a syllable but because it occurs in only one syllable it is classified as a vowel. Indonesian has two most commonly used diphthongs, such as found in the words "sampai" /sampai/ and "kerbau" /korbou/. These diphthongs differ from their English partners in the nature of the first elements. Therefore, imperative for Indonesian students learn English to pay attention to the pronunciation of these English diphthongs. In dividing of diphthong itself, there are eight diphthong sounds and each of the sounds be parted into two kinds of diphthongs. According to Roach (2009:8), there are nine diphthongs [ıә], [əə], [еə],

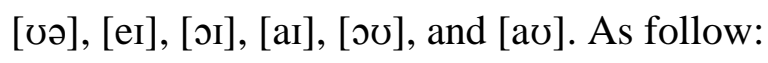

\section{1) Diphthong [ı]}

Diphthong [Iə] is a high- front- centering diphthong. The tongue starts from the vowel [I], and then it glides away in the direction of the central vowel [ə]. The two lips are in neutral position during the vowel glide. 


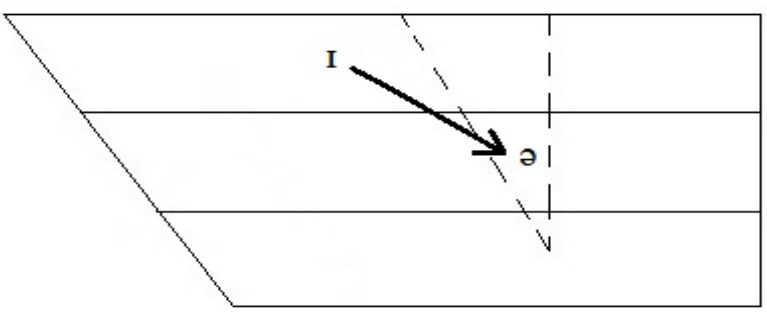

(Source: Ramelan, 2003:95)

\section{2) Diphthong [əə]}

Diphthong [॰ว] is a low back centering diphthong. The tongue starts from the English vowel [o] such as found in the word "call", and then moves in the direction of the central vowel [ə]. The lips are slightly rounded for the first element and are then drawn back to neutral position. The jaws are slightly moving towards each other. This diphthong is now normally replaced by the pure vowel [o:], so that nowadays there is no differentiation with [๑:] and [॰ว].

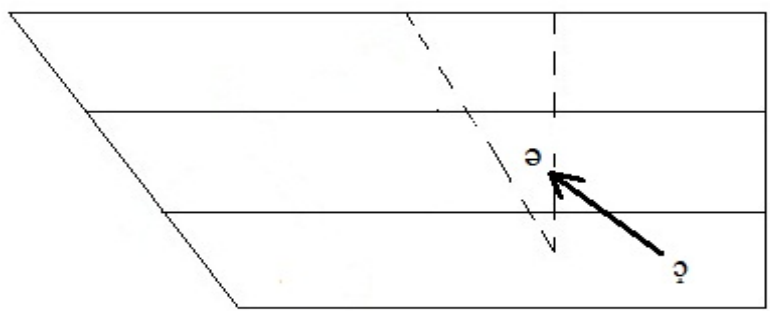

(Source: Ramelan, 2003:97)

\section{3) Diphthong [eə]}

Diphthong [eə] is a low front-centering diphthong. The tongue starts from an open vowel position, slightly higher than the position for the English [æ] vowel sound as found in the word "man", then it glides away in the direction of the central vowel [ə]. The lips are either spread or neutral during the glide. The lower jaw is clearly felt to be slightly moving upward. 


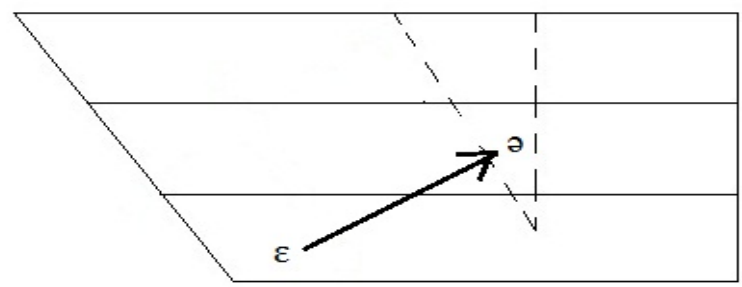

(Source: Ramelan, 2003:96)

\section{4) Diphthong [ซə]}

Diphthong [və] is a high back centering diphthong. The tongue starts from the English vowel $[\mho]$ position such as found in the word "good", and not from the closer [u:]; then, it glides away in the direction of the central vowel [ə]. The lips are rounded for the first element, and are then drawn back to neutral position during the glide.

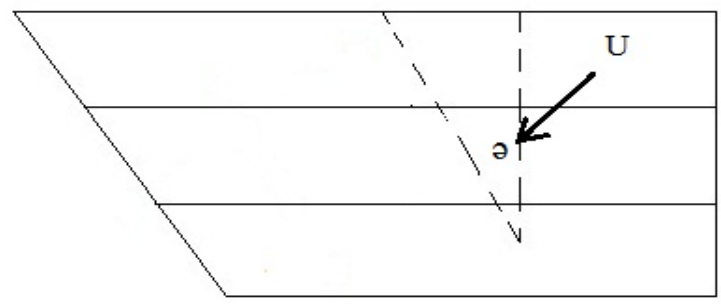

(Source: Ramelan, 2003:97)

\section{5) Diphthong [eI]}

Diphthong $\left[\mathrm{eI}^{\mathrm{I}}\right]$ is a front-front closing half diphthong. First, the tongue starts from the position for the vowel [e], a front vowel which is a little lower than the half close position. Then, the tongue moves in the direction of the vowel position of [I], which is a little above the half close position, though it is not necessarily reached. The lips are spread, and gradually closing.

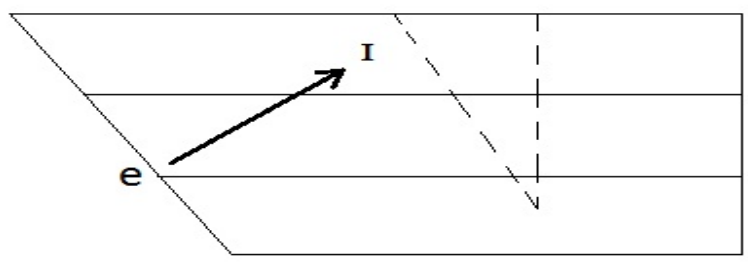




\section{6) Diphthong [эr]}

Diphthong [эI] is a back-front closing full diphthong. First, the back of the tongue is raised to a point midway between [o] and [0:]. Then the front tongue is gradually raised in the direction of [I], though in practice, it is never reached [OI] sounds more or less like [oe]. The lips are rounded for the first element of the diphthong and gradually spread.

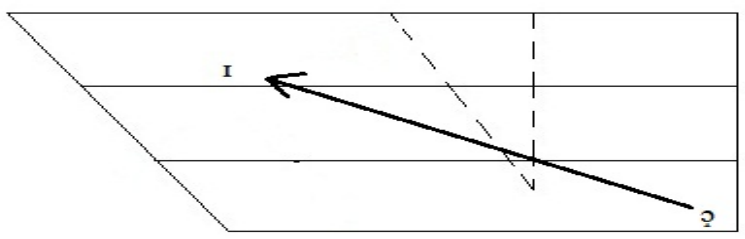

(Source: Ramelan, 2003:91)

\section{7) Diphthong [ar]}

Diphthong [aI] is a front-front closing full diphthong. First, the front of the tongue is very slightly raised for the first element of the diphthong [ar], which is a front vowel with a position in between [æ] and [a:]. Then, the tongue moves to a closer position as if to produce [I] vowel sound, though this position is normally not reached (aI become $æ$ ). The lips are apart and gradually closing.

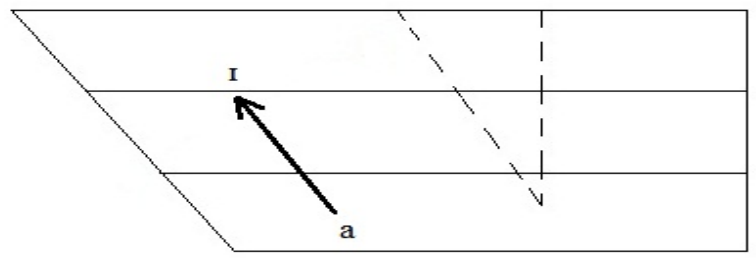

(Source: Ramelan. 2003:86)

\section{8) Diphthong [oo]}

Diphthong [ov] is a back-back closing half diphthong. For the beginning, some parts of the tongue between the back and the center is raised to a point between half-close and half open position. Then, the tongue moves to a closer position in the 
direction of [v], a back centralized vowel, which is a little above the half-close position.

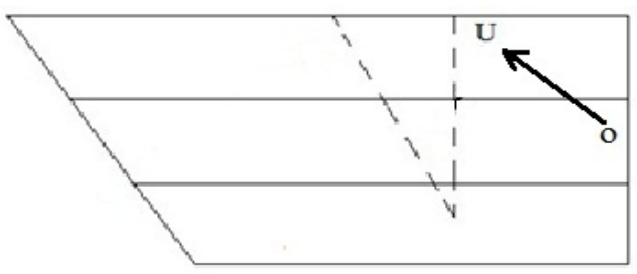

(Source: Ramelan. 2003:86)

\section{9) Diphthong [av]}

Diphthong [a] is a front-back closing full diphthong. First, the front part of the back (central part) of the tongue is slightly raised for the first element of the diphthong $[\mathrm{av}]$. This vowel is more backed than the first element of the diphthong [aI]. Then, the tongue moves in a direction of [ $]$, though it never reaches it ([a $]$ become [ao]). The lips starts at the neutral position, and gradually rounded.

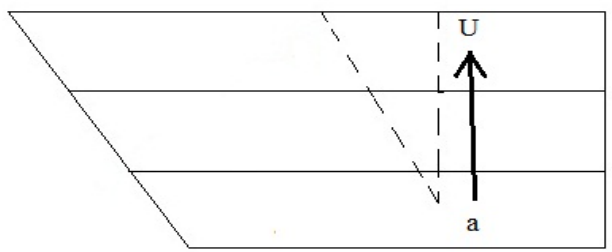

(Source: Ramelan. 2003:89)

The problems which make the students' pronunciation to be inconsistent when they put efforts in learning English language especially in pronunciation sight, which inhibits students to train the students' sensitiveness towards the symbol of sounds in pronunciation, especially in producing the diphthong sounds. The problems are various as Hassan (2014:32-36) points out that he mention on his journal "one of the important problems which always faced by the English learners is inconsistency in pronunciation. Inconsistency itself is the quality or state of being inconsistent in producing the sounds, or lies establishment in scope of statement". In this case, the learners always not in their establishment in pronouncing sounds without hesitation, the learners erroneously changes either the quality of the sound, example: "social 
/'səofl//" some learners do repetition of the word social into “/'spwfl/" by using vowel sound, without using / /əv/ sound in producing the word, then some of students repeat to back into the first right social "/səofl/". The problem of the inconsistencies to foreign and second language learners can not be over emphasized. It explains that pronouncing the English sometimes not perfectly in spelling or producing the sound.

In reading aloud, which observe the spelling words by reading a recitation as the effectively way in reading aloud in pronunciation sight. Kelly (2000:22) claims that, in reading activities, especially reading aloud, although the material is in the form of writing, the pronunciation could be successfully to measure. In some stages, when a text is read aloud either by the students, pronunciation could be measure in producing sounds. Further, reading aloud which includes into the ideal way of reading technique and it is also play important role in mastery English. As Layli (2016:27) stated on her thesis "Reading aloud is one of the ways in which pronunciation is practiced in the classroom. Also reading aloud is a simple technique in reading class which often used in class". It means that, the teachers could be observed the students' pronunciation which is correct or fault in spelling out of reading aloud. Moreover, reading aloud which consist to the activity of learning process which could be something important to be developed.

\section{METHODS}

This research, the researcher conducted this study into qualitative research. It was also supported by Gay, et al (2012:7), "qualitative research is the collection, analysis, and interpretation of comprehensive narrative and visual (nonnumeric) data to gain insight into a particular phenomenon of interest". The researcher tried to analyze the students' inconsistency problems in pronouncing diphthong sounds in reading aloud activity at second year students of English department STKIP PGRI Sumatera Barat.

In this research, to get the data, the researcher needed participants which involved into the research. According to Gay and Airasian (2012:16), participants 
were purposefully selected not randomly and usually fewer in number. It means that, the participants had the important role in this research. The researcher chosen the participants which had taken pronunciation subject on their study in first semester, it was the students at second year of English department STKIP PGRI Sumatera Barat. Therefore, it was expected that it could be easier to analyze their inconsistency problems in pronouncing diphthong sounds in reading aloud activity.

The researcher used purposive sampling method to collect the research of the data. Ary et al (2010:156) explained "In purposive sampling, also referred to as judgment sampling, sample elements judged to be typical, or representative, are chosen from the population. The assumption was that errors of judgment in the selection would counterbalance one another". the researcher needed to prepare for doing the test, cause the instrumentation of this research were tests and video recorder and asked the sample class willingness to be given a test of reading alouud with narrative texts.

\section{FINDING AND DISCUSSION}

As the finding, the students did inconsistency in pronouncing diphthongs [əə], [eI], [aI], and [ov] sounds which the most of the students pronounced the sounds. and the [еə], [эə] and [эг] sounds were partly of the students did inconsistent and pronounced the sounds by incorrect pronunciation in pronouncing the diphthong sounds. However, some students only did mispronouncing, with the sound of [av] was only classified as mispronunciation in produced the sound in the text by the students, and [ซə] sound there was not to be exist word that on the test. Some students were founded doing repetition in producing the sound, and some of them were hesitate to pronouncing the sounds and some other of them were also be careful to what they pronounced and remain how to pronounce the sound in right. It caused the students being inconsistent to pronounce the diphthong sounds. Based on the data 
which has been gotten by the researcher, it could be concluded that students really had problem in pronouncing sounds. The finding would be described as follow:

\section{Diphthong [eI]}

\begin{tabular}{|c|c|c|c|}
\hline \multirow[b]{2}{*}{ Words } & \multirow{2}{*}{$\begin{array}{l}\text { Phonetic } \\
\text { Words } \\
\text { Trans- } \\
\text { cription }\end{array}$} & \multicolumn{2}{|c|}{ Students Produced Sounds (Inconsistent) } \\
\hline & & Vowel & Diph-thong \\
\hline Name & /neIm/ & [e], [a] & [ar] \\
\hline Made & /meId/ & [e] & - \\
\hline Failed & /ferld/ & [e], [a] & [aI] \\
\hline Race & /reis/ & $\begin{array}{c}\text { [e], [a], } \\
{[\mathrm{I}]}\end{array}$ & [aI], [eə] \\
\hline Snail & /sneil/ & [a], [e] & [aI], [eə] \\
\hline $\begin{array}{c}\text { Invitatio } \\
n\end{array}$ & 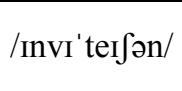 & [e] & - \\
\hline Came & /keIm/ & [a], [e] & - \\
\hline Later & /leita/ & [e] & - \\
\hline
\end{tabular}

\section{Diphthong [I0]}

\begin{tabular}{|c|c|c|c|}
\hline \multirow[b]{2}{*}{ Words } & \multirow{2}{*}{$\begin{array}{c}\text { Phonetic } \\
\text { Words } \\
\text { Trans- } \\
\text { cription }\end{array}$} & \multicolumn{2}{|c|}{ Students Produced Sounds (Inconsistent) } \\
\hline & & Vowel & Diph-thong \\
\hline Friar & /' fraiə/ & $\begin{array}{c}{[\mathrm{I}],[\mathrm{e}],} \\
{[\mathrm{a}]}\end{array}$ & {$[\mathrm{eI}],[\mathrm{e}]$} \\
\hline Deer & /diə/ & $\begin{array}{c}{[\mathrm{I}],[\mathrm{e}],} \\
{[\partial]}\end{array}$ & - \\
\hline Here & /hıə/ & {$[\mathrm{I}],[\mathrm{e}]$} & - \\
\hline
\end{tabular}

\section{Diphthong [aI]}

\begin{tabular}{|c|c|c|c|}
\hline \multirow[b]{2}{*}{ Words } & \multirow{2}{*}{$\begin{array}{l}\text { Phonetic } \\
\text { Words } \\
\text { Trans- } \\
\text { cription }\end{array}$} & \multicolumn{2}{|c|}{ Students Produced Sounds (Inconsistent) } \\
\hline & & Vowel & Diph-thong \\
\hline Advised & /əd'varzd/ & $\begin{array}{c}{[\mathrm{e}],[\mathrm{I}],} \\
{[\mathrm{a}]}\end{array}$ & [eI] \\
\hline Time & $/ \operatorname{taIm} /$ & {$[\mathrm{e}],[\mathrm{a}]$} & [eI] \\
\hline Died & /'daid/ & $\begin{array}{l}{[\mathrm{e}],[\mathrm{a}],} \\
{[\mathrm{I}],[æ]}\end{array}$ & {$[\mathrm{eI}]$} \\
\hline Replied & /ri'plaid/ & $\begin{array}{c}{[\mathrm{e}],[\mathrm{I}],} \\
{[\mathrm{a}]}\end{array}$ & [eI] \\
\hline I'm & /aIm/ & {$[\mathrm{I}],[\mathrm{e}]$,} & {$[\mathrm{eI}]$} \\
\hline
\end{tabular}




\begin{tabular}{|c|c|c|c|}
\hline & & [ə] & \\
\hline While & /wail/ & {$[\mathrm{e}],[æ]$} & [eI] \\
\hline Cried & /kraId/ & $\begin{array}{c}{[\mathrm{e}],[\mathrm{I}],} \\
{[\mathrm{a}]}\end{array}$ & - \\
\hline
\end{tabular}

\section{Diphthong [ov]}

\begin{tabular}{|c|c|c|c|}
\hline \multirow[b]{2}{*}{ Words } & \multirow{2}{*}{$\begin{array}{l}\text { Phonetic } \\
\text { Words } \\
\text { Trans- } \\
\text { cription }\end{array}$} & \multicolumn{2}{|c|}{ Students Produced Sounds (Inconsistent) } \\
\hline & & Vowel & Diph-thong \\
\hline Potion & /'povfən/ & [p] & [OI] \\
\hline No & /nov/ & [p] & - \\
\hline Moment & '/moumənt/ & [D] & - \\
\hline Own & /oun/ & [p] & - \\
\hline So & /sov/ & {$[\mathrm{p}],[\mho]$} & - \\
\hline
\end{tabular}

\section{Diphthong [OI]}

\begin{tabular}{|c|c|c|c|}
\hline \multirow[b]{2}{*}{ Words } & \multirow{2}{*}{$\begin{array}{c}\text { Phonetic } \\
\text { Words } \\
\text { Trans- } \\
\text { cription }\end{array}$} & \multicolumn{2}{|c|}{ Students Produced Sounds (Inconsistent) } \\
\hline & & Vowel & Diph-thong \\
\hline Poison & /'poIzn/ & [p] & 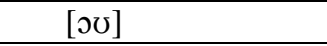 \\
\hline
\end{tabular}

\section{Diphthong [ea]}

\begin{tabular}{|c|c|c|c|}
\hline \multirow{2}{*}{ Words } & \multirow{2}{*}{\begin{tabular}{c} 
Phonetic \\
Words \\
Trans- \\
\cline { 3 - 4 } \\
\cline { 3 - 4 } \\
cription
\end{tabular}} & Vowel & Students Produced Sounds (Inconsistent) \\
\hline There & $/$ /eə/ & {$[\mathrm{e}]$} & Diph-thong \\
\hline
\end{tabular}

\section{Diphthong [or]}

\begin{tabular}{|c|c|c|c|}
\hline \multirow{2}{*}{ Words } & \multirow{2}{*}{$\begin{array}{c}\text { Phonetic } \\
\text { Words }\end{array}$} & \multicolumn{2}{|c|}{ Students Produced Sounds (Inconsistent) } \\
\cline { 3 - 4 } & $\begin{array}{c}\text { Trans- } \\
\text { cription }\end{array}$ & Vowel & Diph-thong \\
\hline More & $/ \mathrm{mos} /$ & {$[\mathrm{p}]$} & - \\
\hline
\end{tabular}

The sounds were pronounced inconsistent by the students, they were [er], [ı], [aI], [əひ], [эI], [eə], and [əə]. The students pronounced diphthong [eI] in the words, the students were mostly pronounced it with using vowel [e] and diphthong [aI] to be inconsistent and pronounced it with other sounds as [a], [I] and [eə]. For diphthong 
[Iə] students were mostly inconsistent pronounced it with [e] and [I] sounds, and also by using [a], [ə], [ег], and [eə]. In pronouncing diphthong [aI] students pronounced the sound with diphthong [er] and vowel [e] as the mostly incorrect to be inconsistent, and other sound of vowels such [I], [a], [æ], and [ə]. Then, diphthong [əひ] was mostly pronounced as [p] sound to be inconsistent it was like with the sounds [or] and [əə],

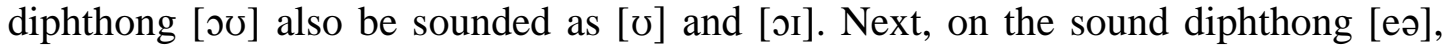
students were mostly pronounced it with [p].

Inconsistent pronunciations happen when the students try to be correct pronunciation clearly, but it is hard to imitate to pronounce the correct pronunciation. It can be because the elements do not exist in the native language. Waridah (2008:4) claims that English has nine diphthongs, but Indonesian only has three diphthongs. They are diphthong [aI], [av], and [эг] which has most commonly used, such as found in the words sampai, kerbau and meridhoi. The researcher interprets that the students still do inconsistency on pronouncing the diphthong sounds. The students also complain that they can not pronounce it well and stand to consistent to the sound production. Therefore, they get stammer and thought how to pronounce the sound.

\section{CONCLUSION}

Based on the findings of the research, there were some sounds that could not be inconsistent to pronounced in reading aloud by the students, the researcher has gotten 9 students to be given test two times. The most inconsistency sounds that the students produced there are [Іә], [eI], [aI], and [əv] sounds whereas the sounds of [eə], [əə], and [эI] a bit of students did inconsistency in pronouncing the sounds, then sound [av] and [və] only did mispronouncing the sounds. As the result of the research, the most students were doing inconsistent sounds when produced [aI] was being [er], [e] and [I]. Next, [er] sound was being [e] and [aI] sounds and [ov] sound was pronounced as [p] sound, and [Iə] sound was pronounced as [I], [e], and [eI] sounds. The caused of inconsistency problems in pronouncing diphthong sounds there were the students were focused to be the native and much to did repetition while 
they pronounced the sounds, the students also got hesitancy to produce the sound, and some of them are stammer while pronouncing the diphthong sounds.

\section{REFERENCES}

Ary, Donald, Lucy Cheser Jacob, and Christine K. Sorensen. 2010. Introduction to Research in Education. Canada: Nelson, Ltd.

Gay, L. R., Geoffrey E. Mills, and Peter W. Airasian. 2012. Educational Research: competencies for analysis and applications. New York: Pearson Education, Inc.

Gilakjani, A.P. 2012. The Significance of Pronunciation in English Language Teaching. English Language Teaching.

Harmer, J. 2007. How to teach English 2nd edn. Pearson Education Ltd. Longman, ISBN1405853093, 9781405853095.

Hassan, E. M. I. 2014. Pronunciation Problems : A Case Study of English Language Students at Sudan University of Science and Technology, 4(4), 31-44. https://doi.org/10.5539/ells.v4n4p31.

Kelly, Gerrald. 2000. How to Teach Pronunciation. Edinburgh: Pearson Education Limited.

Ladefoged, Peter. 2005. Vowels and consonants. Oxford: Blackwell Publishing.

Layli, N. Awalul. 2016. THESIS: Improving Student's Pronunciation by Using Reading Aloud Technique at the Seventh Grade of SMPN 3 Kedungwaru Tulungagung. Jawa Timur: IAIN of Tulungagung.

Ramelan. 2003. English Phonetics. Semarang: IKIP Semarang Press.

Roach, P. 2000. English Phonetics and Phonology: A practical course Cambridge: Cambridge University Press.

Waridah, Ernawati. (2008). EYD dan Seputar Kebahasa-Indonesiaan. Jakarta: Kawah Media. 